\title{
Editorial
}

\section{O nosso protesto}

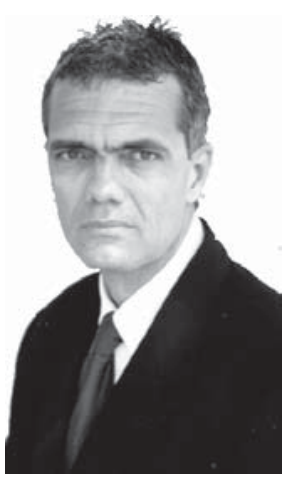

Prof. Dr. Marco Antonio Guimarães da Silva

A idéia deste editorial já estava preconcebida, quando, na madrugada do dia 19 de março, chega a noticia de que o Iraque havia sido invadido pelo “ exército aliado".

Pretendia falar sobre os novos rumos da fisioterapia baseada em evidencias e sobre o convite a mim formulado pela 'World Confederation of Physical Therapy' -WCPT- para que ministrasse curso sobre o tema no Congresso Mundial de Barcelona. Entretanto, a visualização e leitura de notícias sobre este covarde e hipócrita ato invasor, tão assepticamente enquadrado pelas cenas televisivas, apesar de ocorrer há milhares de quilômetros daqui, não diminui a intensidade de nossa revolta e acaba por nos impedir de desenvolver qualquer tema que não se relacione ao fato. Quase que hipnóticamente se é levado a expressar de alguma forma a repugnância ao massacre totalmente injustificável. Sabe Deus que demônios da pior espécie possuíram os responsáveis pela invasão e os fizeram realizar as suas mais cruéis vontades.

O povo Iraquiano, além de ter sido obrigado a conviver por décadas sob o jugo de um cruel tirano, terá agora o constrangimento e dor de ver a sua soberania destroçada e seus filhos assassinados e mutilados pelos temíveis Tomahawk, enviados pelos "senhores da guerra", invasores não menos cruéis.

Bem nos ensina o dito: "A ignorância é prima da maldade." O poder que a primeira possui pode ser mais nefasto e arrasador do que mil bombas. Desse modo, torna-se assustador perceber que, enquanto parte do mundo se põe estupefata frente à ação agressora, outra parte parece que faz a sesta, como que dormindo meio acordada e se locupletando voluptuosamente com o sofrimento e aniquilamento alheio. Anestesiados pela mídia, pela falta de informação, pela mentira e pela cultura do consumo, essas pessoas assistem a um assassinato em massa como quem vê uma partida de vídeogame. Refiro-me a uma boa parcela do povo americano que parece considerar positiva esta guerra, apoiando-a como um ato de justiça, ainda

* Editor cientifico de Fisioterapia Brasil

Pós Doutorado na UFRJ

Professor de mestrado recomendado pela CAPES que ela venha a custar, como conseqüência imediata, a vida de milhares de civis iraquianos, e, como resultado secundário, a paz do próprio povo americano, que, a partir de agora, se sentirá inseguro fora de seu país e até mesmo dentro dele. 
Por forças circunstanciadas ao objeto de estudo da fisioterapia, o fisioterapeuta vê-se na obrigação, em algumas situações, de atender e promover a recuperação funcional de pacientes amputados e portadores de seqüelas oriundas de traumas violentos. Aqueles que em sua vida profissional tiveram oportunidade de atender pacientes mutilados por guerras e conflitos sabem dimensionar, talvez melhor do que ninguém, o grande sofrimento imposto aos que conseguem sobreviver. Estamos, pois, todos nós, cristãos e não cristãos, que prezamos a vida humana, de luto por todo este ato de injustiça, covardia e hipocrisia, a que somos obrigados a assistir.

\section{Recomendações a nossos leitores e autores}

Recebemos cada semana inúmeros trabalhos e agradecemos todos os autores pela confiança em nossa revista. Para agilizar o processo de avaliação, recomendamos a todos seguir atenciosamente as normas de publicação, especialmente no que se refere às referências (numeração na ordem de aparição no texto, redação na norma Vancouver), e aos dados dos autores (nomes e sobrenomes completos, titulação, endereço completo).

Muitos autores enviam fotos e ilustrações, mas com resolução insuficiente para impressão gráfica. Recomendamos enviar as fotos por Internet em arquivo separado, com resolução mínima de 300 dpi no formato TIFF. Caso contrário, é melhor enviar pelo correio as fotos originais, que serão devolvidas após escaneamento. 